\title{
Dimensions of Information Literacy and the Expectations from Librarians in Diverse Environments in Nigeria
}

\author{
Dr. R.O. Attama \\ Polytechnic Librarian, Akanu Ibiam Federal Polytechnic Unwana \\ Ebonyi State, Nigeria \\ Email: okeychyromy@gmail.com
}

Kingsley Nwadiuto Igwe (Corresponding author)

Department of Library and Information Science

Akanu Ibiam Federal Polytechnic Unwana, Ebonyi State, Nigeria

Email: knigwe@yahoo.com

Doi:10.5296/ ijld.v5i2.7608 URL: http://dx.doi.org/10.5296/ ijld.v5i2.7608

\begin{abstract}
This paper articulated various dimensions of information literacy (IL) as well as the expectations from librarians in Nigeria. It examined the emergence of IL and its conceptualisation, and also discussed various dimensions of IL from academic, agricultural, business, media, political and legal perspectives. Expectations from librarians in this multi-literacy era for the delivery of IL education and programmes were also x-rayed; with deficiencies in the IL skills of librarians identified. The paper concluded that librarians should arise to the task of IL delivery to users, and therefore recommended, among others, that practising librarians should articulate and make case for IL programmes in their institutions, there should be continuous professional development programmes on IL for librarians and the integration of IL in the curriculum of library and information science schools in Nigeria.
\end{abstract}

Keywords: Information Literacy, Dimensions, Librarians, Diverse Environments, Nigeria. 


\section{Introduction}

Information literacy is one of those contemporary concepts which some fields of study are laying claim to as part of their body of knowledge. Some of these fields include librarianship, education, curriculum studies, instructional technology, sociology, psychology, and literary studies. The claims by these disciplines are no doubt gradually giving information literacy an interdisciplinary and multidisciplinary approach and status. However, it can be inferred that information literacy is actually a significant component of library and information science (LIS). More so, the merging of information literacy and librarianship together, as a conference theme has contributed in specifically designating information literacy as a sub-set of LIS. But if that is actually the case, are librarians especially in Nigeria, who are found in diverse working environments ready to champion the course of information literacy, bearing in mind various perspectives emerging from the concept? This is an issue of concern.

Some years ago, the concept of information literacy appears as one of those buzzwords and fads that are emerging in the society. At present, it seems the reverse is the case, as the essence of the concept is now applicable to and felt by individuals, researchers, institutions, organizations, corporations and establishments. Today, the concept is fast gaining ground in all sectors of global economy, be it academic, health, agriculture, business, media, politics and the like as the antidote to accomplishment of goals, productivity enhancement, instrument of sustainability and competitive advantage; only when the skills are in possession by individuals involved. In other words, information literacy has developed into various dimensions, thereby establishing its relevance in different areas of human endeavour, as revealed in various empirical studies across the universe. Thus, aligning with the sophistications in our emerging information and knowledge-driven society where data glut and information explosion are the major influencing factors. This is the focus of this paper, with highlights on the expected responsibilities of Nigerian librarians in this multi-literacy era.

Be that as it may, this paper which adopted desk research approach examines the emergence and conceptualization of information literacy, various dimensions of information literacy and their descriptions, and the expectations from librarians in diverse working and operational environments in Nigeria.

\section{Emergence and Conceptualisation of Information Literacy}

What appears as information literacy today took its root from bibliographic instruction, library instruction, use of library, library user education, and library research instruction that have been taught by librarians over the years for library users. These latter concepts underwent an evolutionary process and metamorphosed to a more holistic and acceptable programme tagged information literacy (Skov \& Skoerbak, 2003; Bavakutty \& Nasirudheen, 2008). We may not focus on this historical development considering the fact that it saw information literacy from academic point of view.

Meanwhile, the present use of information literacy (IL) as a concept is attributed to Paul Zurkowski in 1974, when he was the president of the United States Information Industry 
Association, in a proposal he submitted to the National Commission on Libraries and Information Science (NCLIS). According to Zurkowski,

people trained in the application of information resources to their work can be called 'information literates' because they have learnt techniques and skills for utilizing the wide range of information tools as well as primary sources in moulding information solutions to their problems (Behrens, 1994; Bruce, 1997; Zhang, Majid \& Foo, 2010; Uribe-Tirado \& Munoz, 2012).

IL is a self empowering attitude and commitment by individuals and people at all levels of the society to seek, access, analyse, translate, and transform information and create knowledge to solve problems, achieve personal, social, occupational, and learning goals for the improvement of their quality of life (Asamoah-Hassan, 2007). IL is essentially a set of competencies for survival in this era of information explosions. It is a set of skills that are utilitarian in all aspects of a person's life (Mohktar \& Majid, 2008). Individuals with such competences, which may be scientists, lecturers, librarians, teachers, students, administrators, civil servants and the likes apply them in identifying, accessing, evaluating, synthesizing and using information resources responsibly for carrying out their duties, addressing their information-related challenges and become prepared for lifelong learning endeavours. Such ability to seek, find, and decipher information according to Barrack Obama (Weiner, 2013) can be applied to countless life decisions, whether financial, medical, educational, or technical. It is in that direction that Doyle (1994) articulates the overall attributes of an information literate person as one who: recognizes that accurate and complete information is the basis for intelligent decision making; recognizes the need for information; formulate questions based on information needs; identifies potential sources of information; develops successful search strategies; accesses sources of information, including computer-based and other technologies; evaluates information; organises information for practical application; integrates new information into an existing body of knowledge; and uses information in critical thinking and problem-solving.

With the possession of IL skills, one will have the ability to know when there is a need for information, to be able to identify, locate, evaluate, and effectively use that information for the issue or problem at hand. That is why Stem (2002) sees information literacy as the ability to access, evaluate, organize and use information in order to learn, problem-solve, make decisions in formal and informal learning contexts, at work, at home and in educational settings. It is a skill which has been linked with critical and effective thinking, which Prague Declaration stated that it encompasses knowledge of one's' information needs and concerns, and the ability to identify, locate, evaluate, organize and effectively use and communicate information to address issues or problems at hand; it is a pre-requisite for participation in today's society and it is a basic part of the right of lifelong learning (Pejova, Catts, Ticha \& Dombrovska, 2006; Dadzie, 2009). Thus, possession of IL skills in conjunction with access to essential information and effective use of information plays a leading role in reducing the inequalities within and among countries and peoples, thereby bridging the gap among the poor and the rich countries and hence bringing us nearer to achieving the millennium development goals (Shabi, 2012). Importantly, Australian and New Zealand Institute for 
Information Literacy (ANZIIL) presented an all-embracing definition of information literacy as a pre-requisite for participative citizenship, for social inclusion, for the creation of new knowledge, for personal, vocational, corporate and organisational empowerment, as well as for learning for life (Bundy, 2004). Therefore, information literate individuals are expected to be found in all areas of human endeavour. This means that all in the society should possess information literacy skills that will be relevant to their duties, responsibilities and engagements in the present information and knowledge society. No doubt a pressing need is therefore identified, and librarians in diverse working and operational environments in Nigeria should rise up to the task.

\section{Dimensions of Information Literacy}

Dimensions of information literacy as used here means aspects of information literacy involving different areas of human endeavour. Such dimensions include agricultural information literacy, academic information literacy, health information literacy, business information literacy, media information literacy, political information literacy, and even legal information literacy, which Bird (2013) noted that legal information literacy competency standards have been developed to guide the implementation of legal information literacy in developed countries of UK and USA. These dimension are described below.

Academic Information Literacy: This is an area that has virtually dominated studies and discourses in information literacy, which is on educational institutions. It is also an aspect that occupied the root of information literacy from bibliographic instruction to use of library education. Academic information literacy led to the emergence and development of information literacy standards and models by notable library associations such as Association of College and Research Libraries (ACRL) of the American Library Association (ALA), Australian and New Zealand Institute for Information Literacy and Committee of Australian University Librarians (ANZIIL \& CAUL), the Society of College, National and University Libraries (SCONUL) UK, as well as the Chattered Institute of Library and Information Professionals (CILIP), UK. Today, many universities and other educational institutions across the universe have either adopted existing IL standards/models or have developed one to guide their IL education and instruction.

The focus of academic IL is on set of competencies for indentifying, accessing, evaluating, synthesizing and using information resources both print and digital for accomplishing academic tasks, with strict adherence to principles of information ethics such as citation, referencing, and avoiding acts that constitute plagiarism. Possession of academic IL facilitates active engagements in the research process by those in the academia, through knowledge of information search and retrieval, information evaluation, critical thinking, information synthesis, study skills, academic writing skills, and appropriate information utilization, bearing in mind the requisite ethical and legal issues involved as well as participation in knowledge sharing.

In Nigeria today, there are studies with focus on the positive influence of IL on the academia. The investigation by Madu and Dike (2012) revealed that there is a significant relationship between IL competencies and academic productivity of lecturers in north central Nigerian 
universities. In a related study by Okiki and Mabawonku (2013), it was discovered that IL skills had positive influence on academics' research productivity in federal universities in Nigeria. However, many empirical findings as reviewed reported poor IL skills among undergraduate students, and even postgraduate students in various tertiary institutions across the country (Igwe, Uzuegbu, Okite \& Ndubuisi-Okoh, 2014); thus describing information literacy education as a missing issue and neglected ingredient in the educational system of Nigeria in the $21^{\text {st }}$ century.

Agricultural Information Literacy: Agricultural information literacy is mostly for farmers, and other stakeholders in the agricultural sector, with focus on contributing to improvements in agricultural production. Specifically for farmers, Sokoya, Alabi and Fagbola (2014) describe farmers' information literacy as farmer's ability to critically think and determine the extent of his/her information needs and be able to access available information effectively and efficiently, and evaluate the information to accomplish a specific purpose in farming. Agricultural IL is seen as a set of skills and competencies for identifying, accessing and using agricultural information for facilitating enhanced agricultural productivity.

Some empirical investigations have been carried out in the area of agricultural IL. A study carried out by Mashroofa and Senevirathne (2014) on agricultural IL of farmers, shows that facts and information related to format, mode and sources they preferred are indicators that they are not skilled in information literacy. Access to information has a very significant and positive relationship with enhanced agricultural productivity, however factors like poor IL skills, communication gap, and inadequate extension services caused poor access to agricultural information, as identified by Mashroofa and Senevirathne (2014). In a related study by Singh and Singh (2014), they found that agricultural science graduate students have gaps in their information literacy skills as pertain to identifying, interpreting, evaluating and accessing information required for accomplishment of tasks. Another study, while commending FADAMA III programmes for improvement in information and communication flow among farmers that resulted in enhancing farmers, farming and farm production, however, noted that there is much room for continuity and improvement on farmers' information literacy (Sokoya, Alabi \& Fagbola, 2014).

Health Information Literacy: According to Shabi (2012), information literacy is a catalyst for health information seeking and empowerment of individuals in the communities. She described health information literacy as the ability to read, understand and act on health information. Medical Library Association (2014) provided an exhaustive definition of health information literacy (HIL) as 'the set of abilities needed to: recognize a health information need; identify likely information sources and use them to retrieve relevant information; assess the quality of the information and its applicability to a specific situation; and analyze, understand, and use the information to make good health decisions'. The Office of Disease Prevention and Health Promotion as reported by Egunjobi and Akerele (2014) stated that HIL is the ability to obtain, process and understand basic health information and services to make appropriate health decisions. Studies show that as many as half of all adults in all socio-economic level struggle with health literacy and also lack the ability to understand and use the information need to make good health decisions (Egunjobi \& Akerele, 2014; Medical 
Library Association, 2014).

The investigation by Egunjobi and Akerele (2014) revealed that users exhibited low health information literacy and the community information services of public and national libraries were occasionally utilized among users in the areas investigated. The hypothesis tested shows that health information literacy is related to community information services utilization in public and national libraries in southwestern Nigeria. This implies that the possession of high health information literacy skills will enable the people to make appropriate health decisions, use community information services more frequently and thus see public libraries and branches of national libraries as partners in their overall well being, information-wise.

Business Information Literacy: Business Information Literacy (BIL) is described as the ability to understand all the dynamics of business like finance, sourcing of products, good customer care, quality control, competition, advertising, records management, budgeting, credit control, profit margins, and many others (Kinyangui, 2009). It can be seen as a set of skills needed by individuals for identifying, developing, nurturing and sustaining viable businesses and enterprises in the emerging information and knowledge society, notwithstanding the particular environment one is. In other words, BIL can also be referred to as the ability to identify, access, evaluate and use financial and business information so as to understand and make rational decisions related to developing and sustaining businesses and entrepreneurial opportunities (Issa, Igwe \& Ugwuogu, 2014). The emphasis of BIL across the universe is now placed more on knowledge of and possession of financial literacy skills. Central Bank of Nigeria (2012) quoting the Organisation for Economic Co-operation and Development described financial literacy as the process by which consumers improve their understanding of financial products, concepts and risks, and through information, instruction and/or objective, advice, develop the skills and confidence to become more aware of financial risks and opportunities, to make informed choices, to know where to go for help, and take other effective actions to improve their financial well being. The CBN has also developed financial literacy framework for Nigeria, and efforts are being made to make financial literacy an aspect of the curriculum for primary and secondary schools. In addition, many institutions and corporations both public and private in the financial sector as well as non-governmental organizations are making case for financial literacy in the educational system of Nigeria.

Political Information Literacy: According to Badke (2010), the key to a democratic society is the ability of the population to access and handle information effectively and efficiently. Association of College and Research Libraries (2000) notes that information literacy has "broader implications for the individual, the educational system, and for the society" and should advance a mission to help people become "informed citizens and members of communities." If such a mission is to be effective and actualised, however, librarians must develop pedagogies that promote students engagement with the cultural contexts of information literacy, in those communities in which information is created and interpreted. Moreover, librarians must guide students toward recognition of information literacy's value to their lives, specifically its potential for political empowerment (Demering, 2010). In addition, another definition captures information literacy as a set of competencies that an 
informed citizen of an information society ought to possess to participate intelligently and actively in that society. No doubt, the afore-stated perspectives give information literacy a political dimension, thus resulting in political information literacy (PIL). Having broader implications for individuals and the society, advancing a mission for informed citizens and members of communities as well as participating intelligently and actively in a society require that citizens be proficient in identifying, accessing, evaluating and using political information as it concerns their local area, state and the nation in general. This is all about participation in politics, which is described as citizens' involvement in the acts, events or activities that influence the selection of and/or the actions taken by political representatives as well as citizens' engagement in the discourse of socio-political and economic issues which serve as yardsticks for choosing would-be leaders. It may also include the ability to utilize the available information, assessing the capabilities of the incumbents and advocating ways of ameliorating societal ills for a more prosperous country. Political participation include such activities like political discourse, political campaigns, voter registration, the actual voting, writing and signing of petitions, attending civil protests, joining interest groups that engage in lobbying, political advocacy, monitoring and reporting of cases of violation of the electoral process such as frauds, rigging, intimidation, violence, monetary inducements, underage voting, and the like (Okoro \& Nwafor, 2013). Participation in all these productively requires possession of political information literacy skills.

Media Information Literacy: According to IFLA (2011), Media and Information Literacy (MIL) consists of the knowledge, the attitudes, and the sum of the skills needed to know when and what information is needed; where and how to obtain that information; how to evaluate it critically and organise it once it is found; and how to use it in an ethical way. The concept extends beyond communication and information technologies to encompass learning, critical thinking, and interpretative skills across and beyond professional and educational boundaries. MIL is a new emerging field of human rights in an increasingly digital, interdependent, and global world, and promotes greater social inclusion. It can bridge the gap between the information rich and the information poor. MIL empowers and endows individuals with knowledge of the functions of the media and information systems and the conditions under which these functions are performed (IFLA, 2011). MIL also provides a framework to access, analyze, evaluate, create and participate with messages in a variety of forms, from print to video to the Internet. Media literacy builds an understanding of the role of media in society as well as essential skills of inquiry and self-expression necessary for citizens of a democracy (Centre for Media Literacy, 2011). UNESCO (2014) added that MIL recognizes the primary role of information and media in our everyday lives. It lies at the core of freedom of expression and information, since it empowers citizens to understand the functions of media and other information providers, to critically evaluate their content, and to make informed decisions as users and producer of information and media content.

\section{Expectations from Nigerian Librarians in the Multi-Literacy Era}

Librarians in diverse working and operational environments in Nigeria include those in the universities, polytechnics, colleges of education, colleges of agriculture, research institutes, ministries, departments and agencies of governments, public and national libraries, primary 
and secondary schools, among others. They are expected to be delivering or executing IL education for their existing and potential users. This is to enable the users acquire requisite IL skills that will be relevant in their various areas of engagements. It should be noted that the nature of IL skills needed by an undergraduate or a researcher will be different from that of a farmer or an entrepreneur. All individuals in the society need IL skills for progressive living and productive participation.

For academic institutions, with the launch of problem-based and project-based learning as principal study method (Hepworth \& Walton, 2013), which focuses on equipping prospective graduates with core $21^{\text {st }}$ century skills, through the application of different stages like problem definition, problem analysis, research question/hypotheses, research and synthesis (Okike, 2014), IL education is the forerunner for its actualisation in Nigeria. Unfortunately, the situation in Nigerian tertiary institutions may not actualise the intention and mission of problem-based learning. Using the universities and polytechnics as examples, the teaching of Use of Library as an insignificant part of Use of English is not only out-dated, but also no longer acceptable in this information literacy era. The worrisome aspect of this is that librarians of some universities and polytechnics are not even given the opportunity for its delivery, rather both Use of English and Use of Library content are left in the hands of English lecturers to teach. This is rather unfortunate situation.

Meanwhile, it seems many librarians in the university system are not yet aware that the National Universities Commission (NUC) has reviewed the minimum benchmark academic standards for all undergraduate programmes in Nigerian universities, which led to the separation of Use of English from Use of Library. There is now a stand-alone compulsory two (2) units course coded GST 121 with the title 'Use of Library, Study Skills and ICT' (Okojie, 2007), which is expected to be offered by all universities for inculcating IL skills in undergraduate students. Below is the content of the course as it is in the minimum benchmark document:

Brief history of libraries, library and education, university libraries and other types of libraries, study skill (reference services), types of library materials, using library resources including e-learning, e-resources, etc, understanding library catalogues (card, OPAC, etc) and cataloguing and classification (meta data), copyright and its implications, database resources, bibliographic citations and referencing, development of modern ICT, hardware technology, software technology, input devices, storage devices, output devices, communication and internet services, word processing skills.

A critical look at the content shows that it contains the message of information literacy, though with minor elements that are no longer relevant to undergraduate students of nowadays because that are not only digital natives, but also technologically-savvy and core members of the net generation. It is now left for librarians to implement such information literacy programmes, and inculcate practical and relevant information literacy skills in students for productivity in both their academic and future endeavours.

For librarians in public libraries and branches of national libraries across the country, a lot needs to be done in order to attract the attention of the society, which will in turn serve as 
a public relations and advocacy mechanism for them. We are not unmindful of the poor funding system of the libraries, but since they are still existing, their relevance and impact need to be felt by the community they serve, and as such may probably attract favourable attention. Librarians in public libraries should see the need for information literacy programmes for all categories of users, as follows:

- It could be on political information literacy to re-awaken the consciousness of citizens of voting age on the need for healthy participation in political activities of their local area, state and the nation in general in order to project our democracy and contribute to overall national development;

- It could be on health information literacy for the people to be duly informed on critical health issues and hygienic practices as well as precautionary measures to be taken when certain issues/concerns arise;

- It could be on agricultural information literacy for farmers in their various agricultural zones on improved varieties, contemporary farming systems and markets/marketing channels for their products;

- It could be on strategies of developing reading habits for public primary and secondary schools and/or on business information literacy, especially for secondary school students in the area of financial literacy and entrepreneurial skills; among others.

All these could be carried out as part of corporate social responsibility by the public libraries and branches of national library in the country, with or without the involvement of resource persons because librarians are subject specialists. Even librarians in academic libraries can do the same for rural or urban dwellers in their host communities.

Librarians in other working environments should develop IL programmes for their users, and work towards management approval and subsequent implementation, provided the learning objective and expected outcome will be actualized as articulated.

\section{Conclusion and Recommendations}

Librarians have subject specialisations in their education and training that will enable them to be carrying out information literacy programmes for diverse information users. Meanwhile, as the digital era continues to grow and influence library and information services with explosions of information resources, librarians should note that one of the key services they may be concerned with in the near future is IL education for all environments and instructions in the research process for academic institutions. They should be prepared to carry out the task, since it is a core aspect of their job. However, it seems majority of Nigerian librarians are not yet ready to execute IL education in their various environments. This is attributed to the fact that a greater percentage of the librarians in academic libraries in Nigeria are not information literate (Ojedokun, 2014; Anyaoku, Ezeani \& Osuigwe, 2014). Thus, they do not possess adequate IL skills for the inculcation of same to information users. It is a fact that a teacher cannot offer what he/she does not have. In addition, it appears that the curriculum of 
many LIS schools have neglected information literacy; may be thinking that students (.i.e. would-be librarians) will develop their IL skills without being taught.

In view of the above submissions, it is therefore recommended that:

i. Continuous professional development programmes in the area of information literacy should be organized for librarians either by Librarians Registration Council of Nigeria and/or by the state chapters of the Nigerian Library Association with competent resource persons.

ii. LIS schools in Nigeria should see information literacy as a course that must be integrated in their curriculum. For undergraduate students, it can be structured into two introduction to information literacy at 100 level and advanced information literacy at 400 level. Whereas for postgraduate students, there should be courses on information literacy for PGDLIS, MLIS and PhD, that will focus on the various IL skills and how to implement IL programmes in their various working places.

iii. Practising librarians in Nigerian tertiary institutions should articulate information literacy education/ programme as two units credit course for both undergraduates and postgraduate students, which should be forwarded to their institutional management for consideration, approval and subsequent implementation. In a case whereby management of tertiary institutions refuse to accept such proposal, which may be due to some reasons or poor articulation on the part of librarians, librarians have another option of taking advantage of the social media platforms. They may consider developing library blog, and then upload the content of such information literacy programme there. They should also be ready to respond to user queries in such blogs, which are usually interactive.

\section{References}

Anyaoku, E.N., Ezeani, C.N. \& Osuigwe, N.E. (2014). Building a knowledge society:

information literacy skills and practices of librarians in universities in South East Nigeria. Paper presented at $52^{\text {nd }}$ Annual National Conference of the Nigerian Library Association, held at Enugu, Nigeria, $22^{\text {nd }}-27^{\text {th }}$ June, 2014.

Asamoah-Hassan, H (Ed.)(2007). Sub-saharan African colloquium on information literacy and lifelong learning. Addis Ababa, Ethiopia: IFLA/ALP

Association of College and Research Libraries (ACRL)(2000). Information literacy competency standards for higher education. Chicago: Association of College and Research $\begin{array}{lllll}\text { Libraries. } & \text { Retrieved } & \text { May } & 2010 & \text { from }\end{array}$ www.acrl.org/ala.mgrps/divs/acrl/stndards/standards.pdf

Badke, W. (2010). Foundations of information literacy: learning from Paul Zurkowski. ONLINE, Jan/Feb 2010, 48 - 50. Retrieved July 5, 2013 from www.onlinemag.net

Bavakutty, M. \& Nasirudheen, T.P.O. (2008). Assessing information literacy competency of research students in India: a case study. In: A. Abdullah, et al (Eds.) ICOLIS (pp 109 - 121). 
Kuala Lumpur: LISU, FCSIT.

Behrens, S. J. (1994). A conceptual analysis and historical overview of information literacy. College and Research Libraries, 55(4), 309 - 322

Bird, R. (2013). Legal information literacy standards: an over of the developments in US and the UK. Retrieved October 24, 2014 from http://legalinformationliteracy.files.wordpress.com/2013/11/presentatie-ruth-bird-.pdf

Bruce, C. (1997) The seven faces of information literacy. Adelaide: Auslib Press.

Bruce, C. S. (1997). The relational approach: a new model for information literacy. The New Review of Information and Library Research, 3, 1 - 22.

Bundy, A. (ed.) (2004). Australian and New Zealand information literacy framework: principles, standards and practice. $2^{\text {nd }}$ ed. Adelaide: ANZIIL

Central Bank of Nigeria (2012). Framework for financial literacy in Nigeria. Retrieved October 13, 2014 from www.cbn. Gov.ng

Centre for Media Literacy (2011). Media literacy: a definition and more. Retrieved October 25, 2014 from http://www.medialit.org/media-literacy-definition-and-more

Detmering, R. (2010). Exploring the political dimensions of information literacy through popular film. Louisville, KY: University of Louisville. Retrieved October 31, 2014 from https://www.press.jhu.edu/journals/portal_libraries_and_the_academy/portal_pre_print/curre nt/articles/10.3detmering.pdf

Dadzie, P.S. (2009). Information literacy in higher education: overview of initiatives at two Ghanaian universities. African Journal of Library, Archives and Information Science, 19 (2), $165-175$.

Doyle, C.A. (1994). Information literacy in an information society: a concept for the information age. Syracuse, NY: ERIC Clearing House on Information Technology.

Egunjobi, R.A. \& Akerele, J.A. (2014). Health information literacy as a predictor of community information services utilization among citizens in public and national libraries in southwestern Nigeria. Library Philosophy and Practice. Retrieved October 28, 2014 from http://digitalcommons.unl.edu/libphilprac/1148/

Hepworth, M. \& Walton, G. (Eds.)(2013). Developing people's information capabilities: fostering information literacy. Bingley, UK: Emerald Group Publishing

IFLA (2011). IFLA media and information literacy recommendations. Retrieved October 22, 2014 from http://www.ifla.org/publications/ifla-media-and-informationliteracy-recommendations

Igwe, K.N., Uzuegbu, C.P., Okite, M.O. \& Ndubuisi-Okoh, E.O. (2014). Information literacy education: a missing issue in the educational system of Nigeria in the $21^{\text {st }}$ century. Paper presented at the $1^{\text {st }}$ National Conference of the College of Agricultural and Science Education, 
Michael Okpara University of Agriculture Umudike, Abia State, Nigeria, with the theme, ' $21^{\text {st }}$ century issues in education', $1^{\text {st }}-4^{\text {th }}$ July, 2014.

Issa, A.O., Igwe, K.N. \& Ugwuogu, U.O (2014). Business information literacy competencies for entrepreneurs. In: A.O. Issa, C.P. Uzuegbu \& M.C. Nwosu (Eds). Entrepreneurship studies and practices in library and information science (pp. 91 - 108). Umuahia, Nigeria: Zeh Communications

Kinyanjui, J. (2009). Business information competencies with reference to information literacy amongst women entrepreneurs in Kenya and South Africa: a value-added product for economic empowerment. ProLISSA Conference . Retrieved October 122013 from from http://www.unisa.ac.za/default.asp? Cmd=ViewContent\&ContentID=22095

Madu, E.C. \& Dike, V.W. (2012). An assessment on the relationship between information literacy competencies and academic productivity amongst staff of Nigerian universities in North Central Geo-political zone. Journal of Emerging Trends in Computing and Information Sciences, 3 (2), $179-185$.

Mashroofa, M.M. \& Senevirathne, W. (2014). Influence of information literacy skills in accessing agricultural information with special reference to Paddy Farmers of Ampara District, Sri Lanka. Paper presented at IFLA Conference in Lyon, July 21 - 25, 2014.

Medical Library Association (2014). What is health information literacy? Retrieved November 3, 2014 from https://www.mlanet.org/resources/healthlit/define.html

Mohhtah, I.A. \& Majid, S. (2008). Information literacy standards, guidelines and their implementation: an analysis. DESIDOC Journal of Library and Information Technology, 28 (2), $5-12$.

Ojedokun, A.A. (2014). Information literacy competencies of librarians in southwest Nigerian university libraries. African Journal of Library, Archival and Information Science, 24 (1), 67 -90 .

Okike, E (2014). Covenant University to adopt problem based learning. Retrieved October 10, 2014 from http://covenantuniversity.edu.ng/News/Covenant-University-to-Adopt-Problem-Based-Learni ng\#.VA68nihenIU

Okiki, O.C. \& Mabawonku, I. (2013). Impact of information literacy skills on academic staff research productivity in Nigerian federal universities. Information and Knowledge Management, 3 (2), 9 - 18.

Okojie, J. (2007). Benchmark minimum academic standards for undergraduate programmes in Nigerian Universities. Abuja: NUC.

Okoro, N. \& Nwafor, K.A. (2013). Social media and political participation in Nigeria during the 2011 general elections: the lapses and the lessons. Global Journal of Arts, Humanities and Social Sciences, 1 (3), $29-46$. 


\section{Macrothink}

International Journal of Learning \& Development

ISSN 2164-4063 2015, Vol. 5, No. 2

Pejova, Z., Catts, R., Ticha, L., \& Dombrovska, M. (Eds). (2006). Achieving an information society and a knowledge-based economy through information literacy: Proposal for an information literacy platform and an action plan for central and south-east European countries. Ljubljana: ICPE.

Shabi, I.N. (2012). Information literacy: a catalyst for health information seeking and empowerment among women in rural communities in Nigeria. PNLA Quarterly, 76 (3), 66 74. Retrieved July $10, \quad 2013$ from http://www.pnla.org/assets/documents/Quarterly/pnlaq76-3-spring2012.pdf

Singh, N. \& Singh, N. (2014). Educating for information literacy: assessing Indian agricultural science graduates knowledge and information skills. Library Philosophy and Practice (e-journal). Paper 1102. Retrieved November 3, 2014 from http://digitalcommon.unl.edu/libphilprac/1102

Skov, A. \& Skoerbak, H. (2003) Fighting an uphill battle: teaching information literacy in Danish institutions of higher education. Library Review, 52(7), 326 - 332.

Sokoya, A.A., Alabi, A.O. \& Fagbola, B.O. (2014). Farmers' information literacy and awareness towards agricultural produce and food security: FADAMA III programs in Osun state, Nigeria. Paper presented at IFLA Conference in Lyon, July 21 - 25, 2014.

UNESCO (2014). Communication and information: media and information literacy. $\begin{array}{llll}\text { Retrieved } & \text { October } & 18, & 2014\end{array}$ http://www.unesco.org/new/en/communication-and-information/media-development/media-li teracy/mil-as-composite-concept/

Uribe-Tirado, A. \& Munoz, W.C. (2012). Information literacy competency standards for higher education and their correlation with the cycle of knowledge generation. Liber Quarterly, 22 (3), 213 - 239.

Weiner, S. A. (2013) Plenary session: the state of information literacy policy: a global Priority. Libraries, Faculty and Staff Presentations of Purdue University USA. Paper 32. Retrieved February 14, 2014 from http://docs.lib.purdue.edu/lib_fspres/32

Zhang, X., Majid, S. \& Foo, S. (2010). Environmental scanning: an application of information literacy skills at the workplace. Journal of Information Science, 36 (6), 719 - 732. Doi: 10:1177/0165551510385644. 